\title{
Aplikasi Jaringan Syaraf Tiruan sebagai Metode Alternatif Prakiraan Beban Jangka Pendek
}

\author{
Dadad Zaenal, SE., M.Kom. \\ Dosen Program Studi Manajemen Informatika \\ Politeknik LP3I Bandung \\ Email : dadadzaenalm@yahoo.com
}

\begin{abstract}
Abstrak : Untuk memenuhi permintaan daya dari konsumen secara ekonomis suatu perusahaan listrik harus bisa memprakirakan beban secara akurat. Sistem prakiraan beban terbaik di negara-negara maju dengan menggunakan teknologi Jaringan Syaraf Tiruan (JST). Artikel ini mengungkap penelitian awal pemakaian JST Backpropagation untuk prakiraan beban di area 3 PLN yang dilakukan penulis dengan biaya sendiri.
\end{abstract}

Keunggulan utama JST adalah kemampuan komputasi yang pararel dengan cara belajar dari pola-pola yang diajarkan. Dalam proses belajarnya JST dapat melakukan regresi non-linier pola-pola beban listrik tiap jan dalam satu hari. Sehingga JST mampu memprakirakan beban listrik pada hari yang akan datang.

Kata kunci : Jaringan syaraf tiruan, backpropagation, prakiraan beban, pengaruh cuaca

\section{Pendahuluan}

Tenaga Listrik tidak dapat disimpan dalam skala besar, karenanya tenaga ini harus disediakan pada saat dibutuhkan. Akibatnya timbul persoalan dalam menghadapi kebutuhan daya listrik yang tidak tetap dari waktu ke waktu, bagaimana mengoperasikan suatu sistem tenaga listrik yang selalu dapat memenuhi permintaan daya pada setiap saat, dengan kualitas baik dan harga yang murah. Apabila daya yang dikirim dari bus-bus pembangkit jauh lebih besar daripada permintaan daya pada bus-bus beban, maka akan timbul persoalan pemborosan energi pada perusahaan listrik, terutama untuk pembangkit termal. Sedangkan apabila daya yang dibangkitkan dan dikirimkan lebih rendah atau tidak memenuhi kebutuhan beban konsumen maka akan terjadi pemadaman lokal pada bus-bus beban, yang akibatnya merugikan pihak komsumen. Oleh karena itu diperlukan penyesuaian antara pembangkitan dengan permintaan daya.

Syarat mutlak yang pertama harus dilaksanakan untuk mencapai tujuan itu adalah pihak perusahaan listrik mengetahui beban atau permintaan daya listrik dimasa depan. Karena itu prakiraan beban jangka pendek, menengah dan panjang merupakan tugas yang penting dalam perencanaan dan pengoperasian sistem daya. Prakiraan beban jangka pendek, yaitu beban setiap jam atau tiap hari digunakan untuk penjadualan dan pengontrolan sistem daya atau alokasi pembangkit cadangan berputar, juga digunakan untuk masukan dalam studi aliran daya. 


\section{Jaringan Syaraf Tiruan Backpropagation}

Jaringan Syaraf Tiruan (JST) adalah model sistem komputasi yang bekerja seperti sistem syaraf biologis pada saat berhubungan dengan 'dunia luar', nama jaringan syaraf tiruan merupakan terjemahan dari "Artificial Neural Network". Terjemahan yang diambil bukan jaringan syaraf buatan seperti dalam menterjemahkan Artificial Inteligent (AI). Penggunaan kata buatan dapat memberikan konotasi, bahwa manusia berusaha membuat jaringan syaraf aslinya. Padahal maksud dari JST adalah membuat model sistem komputasi yang dapat menirukan cara kerja jaringan syaraf biologis.

Model JST yang digunakan dalam penelitian ini adalah arsitektur feedforward (umpan maju). Sedangkan konsep belajar yaitu algoritma belajar backpropagation momentum yang merupakan perkembangan dari algoritma belajar backpropagation standar.

\subsection{Struktur Jaringan Syaraf Tiruan Backpropagation}

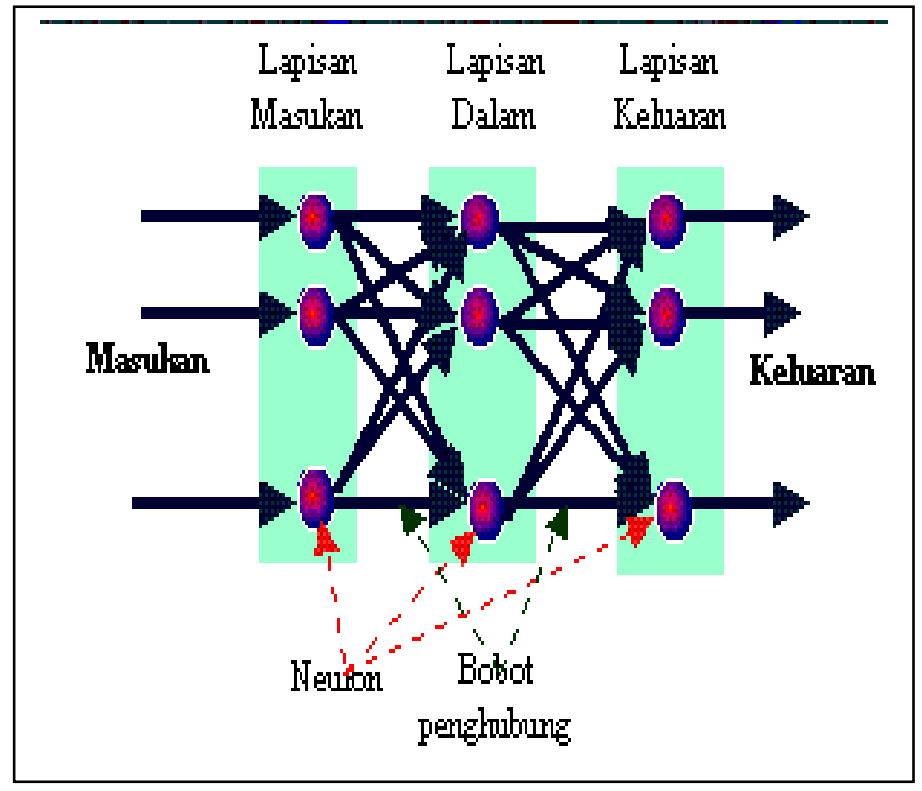

Gambar 1. JST Backpropagation Dengan Satu Laposan Dalam

Jaringan Syaraf Tiruan Backpropagation (BP) pertama kali diperkenalkan oleh Rumelhart, Hinton dan William pada tahun 1986, kemudian Rumelhart dan Mc Clelland mengembangkannya pada tahun 1988.

Asitektur jaringan BP dengan satu lapisan dalam ditunjukan pada gambar 1 . Gambar tersebut menunjukan arah sinyal pada fase feedforward. Selama operasi fase pelatihan backpropagation $(B P)$, sinyal-sinyal error dikirim dalam arah sebaliknya. 
Jaringan syaraf tiruan tersusun atas sekumpulan elemen pemroses (neuron) atau simpul atau sel yang terinterkoneksi dan terorganisasi dalam lapisan-lapisan. Setiap sel memproses sinyal dengan fungsi akivasinya yaitu fungsi sigmoid logistik, fungsi ini analog dengan

$$
f(x)=1 /\left(1-e^{-x}\right) .
$$

Tiap-tiap lapisan terdiri dari banyak simpul, interkoneksi hanya terjadi antara simpul-simpul yang terletak pada satu lapisan dengan simpul-simpul yang terletak pada lapisan tetangganya. Simpul-simpul yang berhubungan langsung dengan masukan dan terletak dalam satu lapisan yang sama, lapisan tersebut disebut "lapisan masukan" simpul-simpul yang memberikan keluaran dan terletak dalam satu lapisan disebut "lapisan keluaran".

Simpul-simpul yang terletak dalam satu atau beberapa lapisan dan tidak berhubungan langsung dengan keadaan di luar jaringan disebut "lapisan dalam" atau lapisan tersembunyi.

Banyaknya simpul pada lapisan masukan dan lapisan keluaran tergantung pada jenis pemakaian tertentu.

\subsection{Algoritma Pelatihan Backpropagation}

Keunggulan yang utama dari sistem jaringan syaraf tiruan adalah kemampuan untuk "belajar" dari contoh yang diberikan.

Algoritma belajar yang digunakan adalah algoritma Backpropagation. Pada algoritma ini digunakan sinyal referensi dari luar (sebagai pengajar) dibandingkan dengan sinyal keluaran JST, hasilnya berupa sinyal kesalahan.

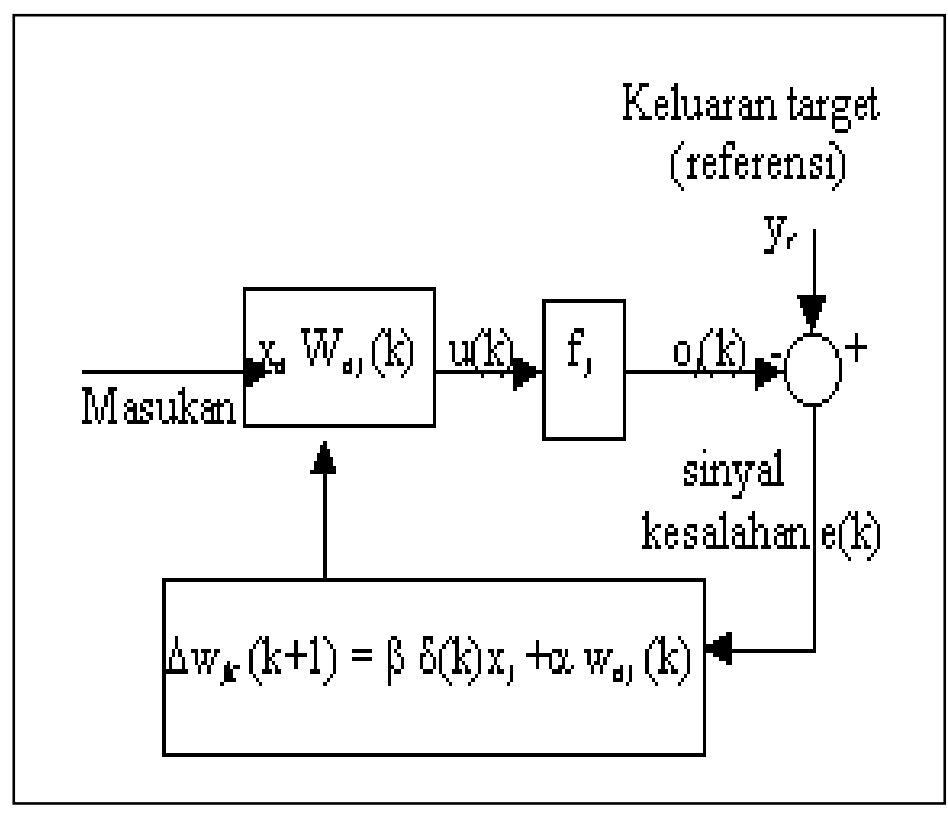

Gambar 2. Blok Diagram Algoritma Belajar Backpropagation 
Keterangan :

$\mathrm{x}$ vektor masukan pelatihan :

$\mathrm{x}=\left(\mathrm{x}_{1}, \ldots \ldots, \mathrm{x}_{\mathrm{i}}, \ldots \ldots, \mathrm{x}_{\mathrm{n}}\right)$.

$\mathrm{y}_{\mathrm{r}}$ vektor keluaran target :

$\mathrm{y}_{\mathrm{r}}=\left(\mathrm{y}_{1}, \ldots ., \mathrm{y}_{\mathrm{k}}, \ldots ., \mathrm{y}_{\mathrm{m}}\right)$.

$\square_{\square}$ porsi koreksi kesalahan untuk pengaturan bobot $\mathrm{w}_{\mathrm{nj}}$.

konstanta laju belajar.

konstanta momentum.

$\mathrm{w}_{\mathrm{nj}}$ bobot koneksi antara sel $\mathrm{n}$ ke sel $\mathrm{j}$.

Dasar dari algoritma ini adalah memodifikasi bobot interkoneksi $\mathrm{W}_{\mathrm{nj}}$ pada jaringan sehingga sinyal kesalahan mendekati nol, untuk lebih jelasnya lihat gambar 2.

Suatu jangka waktu (disebut epoch) adalah satu set putaran vektor-vektor pelatihan. Beberapa epoch diperlukan untuk pelatihan sebuah JST BP sehingga kesalahan mendekati nol.

Selama ini belum ada konsensus mengenai besarnya nilai. dan. yang harus digunakan dalam proses belajar. Sebab dalam kenyataannya tergantung pada permasalahan yang dihadapi.

\section{Prakiraan Beban Jangka Pendek Menggunakan JST}

Pola kegiatan konsumen pada hari kerja yaitu hari Senin sampai hari Jumat dan hari akhir pekan, pada setiap minggunya tidak akan banyak berubah. Pola kegiatan konsumen akan berulang pada setiap minggunya. Pengulangan ini juga akan terjadi pada pola kurva beban dari minggu ke minggu, dimana hari yang sama pada suatu minggu mempunyai pola kurva beban yang mirip. Misalnya pola kurva beban hari Kamis dalam minggu ini akan mirip dengan pola kurva beban pada hari Kamis dalam minggu yang akan datang. Hal yang sama juga terjadi pada hari-hari lain.

Pengalaman praktis operator UPB PLN Banjaran menunjukan bahwa beban listrik pada suatu hari dipengaruhi oleh beban pada hari-hari sebelumnya.

\subsection{Kasifikasi Beban}

Berdasar dari hasil wawancara penulis dengan operator di UPB Banjaran dan pengamatan pada data beban harian dengan pertimbangan kemudahan dalam perhitungan dan keakuratan hasil prakiraan beban, dilakukan klasifikasi pola beban harian sebagai berikut :

- Pola-pola hari biasa yaitu hari Senin sampai Minggu yang bukan hari libur nasional, diklasifikasikan sebagai berikut :

1. Pola beban hari Senin. 
2. Pola beban hari Selasa.

3. Pola beban hari Rabu.

4. Pola beban hari Kamis.

5. Pola beban hari Jumat.

6. Pola beban hari Sabtu.

7. Pola beban hari Minggu.

- Pola hari-hari tidak biasa yaitu hari-hari Senin sampai Minggu yang merupakan hari libur nasional (hari khusus), diklasifikasikan sebagai berikut :

1. Pola beban Tahun baru,

2. Pola beban Proklamasi,

3. Pola beban Isra' mi'raj,

4. Pola beban Puasa Perdana,

5. Pola beban Nyepi,

6. Pola beban Idul Fitri I,

7. Pola beban Idul Fitri II,

8. Pola beban Wafat Isa Al Masih,

9. Pola beban Kenaikan Isa Al Masih,

10. Pola beban Idul Adha,

11. Pola beban Waisak,

12. Pola beban 1 Muharam,

13. Pola beban Maulud Nabi Muhammad S.A.W dan

14. Pola beban Natal.

Sehingga terdapat 7 pola untuk hari biasa dan 14 pola untuk hari khusus (21 jenis pola beban). Selanjutnya beban dalam satu hari (hari i ) dibagi menjadi 24 yang disebut beban tiap jam $\left(\mathrm{l}_{(\mathrm{i}, \mathrm{t})}, \mathrm{t}=1,2, \ldots \ldots ., 24\right)$. Hal ini adalah sesuai dengan tujuan prakiraan beban jangka pendek yang memprediksi beban tiap jam dalam satu hari yang akan datang.

Telah dijelaskan bahwa beban pada suatu hari dipengaruhi oleh beban pada hari yang lalu.

Sifat kecenderungan beban tersebut digunakan sebagai dasar sistem prakiraan beban di PLN dan pada penelitian ini.

Berikut ini adalah variabel masukan yang dipilih :

Hari-hari biasa:

1. Beban tiap jam selama 2 hari yang lalu, yaitu $\mathrm{l}_{(\mathrm{i}-1)}$ dan $\mathrm{l}_{(\mathrm{i}-2)}: 48$ nilai.

2. Informasi cuaca di tiga daerah (Bandung, Subang dan Banjaran) pada dua hari yang lalu tersebut, yaitu curah hujan (besar hujan): 6 nilai.

3. Prakiraan cuaca di tiga daerah diatas, yaitu mengenai kondisi hujan (berawan) atau tidak hujan pada hari yang akan datang (hari yang akan diperkirakan bebannya) : 3 nilai. 


\section{Hari-hari khusus :}

1. Beban tiap jam pada 2 hari minggu terdekat yang lalu, yaitu $1_{(\mathrm{i}-1)}$ dan $\mathrm{l}_{(\mathrm{i}-2)}$ : 48 nilai.

2. Informasi cuaca di tiga daerah (Bandung, Subang dan Banjaran) pada dua hari minggu lalu tersebut, yaitu curah hujan (besar hujan) : 6 nilai..

3. Prakiraan cuaca di tiga daerah diatas, yaitu mengenai kondisi hujan (berawan) atau tidak hujan pada hari yang akan datang (hari yang akan diperkirakan bebannya) : 3 nilai.

Jadi variabel masukan pada JST baik hari biasa maupun hari khusus terdapat $48+$ $6+3=57$ nilai.. Sedangkan variabel keluaran adalah beban tiap jam selama 24 jam yang diperkirakan $=24$ nilai.

\subsection{Arsitektur Jaringan Yang Digunakan Untuk Prakiraan Beban}

Arsitektur Jaringan Syaraf Tiruan Backpropagation Momentum digunakan untuk sistem prakiraan beban listrik jangka pendek di Jawa Barat dan DKI Jakarta ditunjukan pada gambar 3 .

Jaringan Syaraf Tiruan Backpropagation Momentum yang digunakan memiliki 4 lapis, yaitu 1 lapisan masukan, 2 lapisan dalam (hiden layer) dan 1 lapisan keluaran.

Lapis masukan terdiri dari 57 buah sel yang merupakan banyaknya vektor masukan jaringan. Jumlah sel lapisan dalam ke-1 adalah 75 sel, sedang lapisan lapisan dalam ke-2 adalah

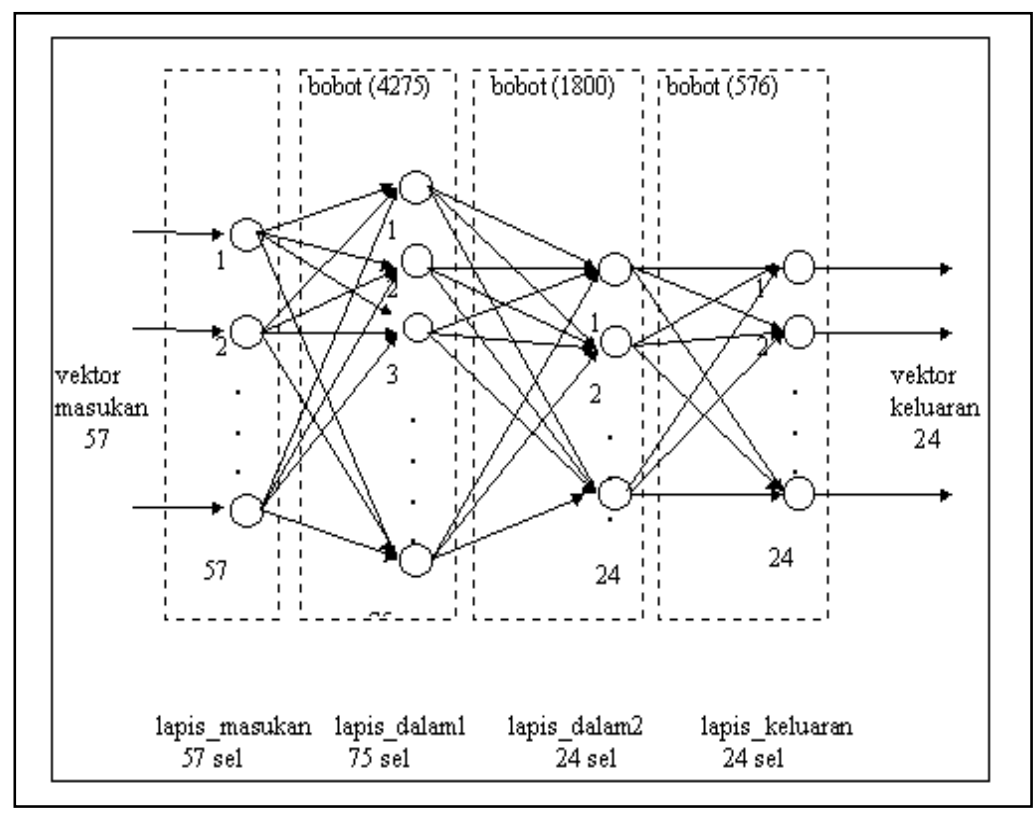

Gambar 3. Arsitektur Jaringan Saraf Tiruan 
Backpropagation Digunakan Untuk Sistem Prakiraan Beban Listrik 24 sel (ditentukan secara acak, karena belum ada ketentuan yang mengatur jumlah lapis dalam dan jumlah sel pada lapis ini). Lapis keluaran adalah 24 sel yang merupakan vektor keluaran JST, yaitu beban tiap jam dalam satu hari yang diprakirakan. JST tersebut memetakan suatu sistem 57 dimensi ke 24 dimensi.

\subsection{Prakiraan Secara On-Line}

Sesuai dengan karakteristik JST, secara umum sistem prakiraan beban dalam penelitian ini terdiri dari dua mode, yaitu mode tahap belajar dan mode tahap pengujian. Mode tahap belajar atau pelatihan merupakan tahap penyesuaian bobot-bobot jaringan. Dalam mode ini diberikan data pola pelatihan yaitu pasangan masukan dan keluaran target yang disimpan dalam file disk (file pelatihan). Dari pasangan-pasangan pola tersebut Jaringan dilatih memprakirakan beban yang terdiri dari 7 pola hari-hari biasa dan 14 pola hari-hari khusus. Hasil pelatihan adalah bobot-bobot koneksi antar sel.

Mode tahap pengujian merupakan sistem prakiraan beban yang dipakai. Dalam mode ini diberikan data masukan yang disimpan dalam file disk (file pengujian). JST yang telah dilatih akan mengambil data masukan tersebut dan memberikan keluaran yang merupakan "Beban Prakiraan JST" yaitu beban tiap jam selama 24 jam yang diprakirakan. JST memberikan keluaran berdasarkan bobot yang disimpan pada mode pelatihan.

Pada akhir mode pengujian dilakukan perbandingan antara beban prakiraan (keluaran JST) dan beban asli (beban kenyataan yang terjadi). Hal ini adalah untuk menguji tingkat keberhasilan JST dalam memprakirakan beban. Setelah proses perbandingan selesai data masukan untuk pengujian dan data beban asli secara otomatis ditambahkan dalam file pelatihan dianggap sebagai pola baru (proses on-line). Oleh karena itu untuk pelatihan berikutnya tidak perlu dilakukan pemasukan data pelatihan kedalam file pelatihan. Hal ini adalah merupakan sifat flexibility JST apabila dijumpai perubahan pola beban listrik.

\section{Pengamatan Hasil}

Setelah melakukan pelatihan untuk pola beban hari biasa (Senin - Minggu) selama 7 minggu (27 Desember 2003 sampai 13 Februari 2004 dilakukan pengujian jaringan yaitu untuk memprakirakan beban. Dalam Hal ini jaringan dicoba untuk memprakirankan beban dari tanggal 14 Februari 2004 sampai 20 Februari 2004.

Dengan pelatihan untuk pola beban hari Maulud Nabi Muhammad SAW. pada 2003, 2004 dan 2005 (3 pola pelatihan), jaringan digunakan untuk memprakirakan beban (pengujian jaringan) pada hari Maulud Nabi Muhammad SAW. 28 Juli 2006. 
Hasil prakiraan beban dengan JST ini kemudian dibandingkan dengan beban aslinya (beban kenyataan yang dihadapi PLN di Jawa Barat dan DKI Jakarta) dan beban prakiraan UPB Banjaran. Hasil perbandingan prakiraan beban tersebut disajikan dalam tabel 1. Dalam tabel 1 tersebut ditunjukan pula besarnya \% error hasil prakiraan beban menggunakan JST dan \% error hasil prakiraan beban UPB. Nilai \% error didapat dari deviasi antara beban prakiraan dengan beban asli terhadap beban prakiraan. Perbandingan data beban prakiraan dan beban asli tersebut secara grafis disajikan dalam gambar 4 sampai dengan 7. Dari gambargambar tersebut dengan mudah dapat dilihat penyimpangan beban prakiraan dengan beban asli (aktual).

Error rata-rata hasil prakiraan beban dengan JST relatif lebih besar dari pada error rata-rata prakiraan beban dengan metode koefisien (UPB). Hal ini disebabkan oleh beberapa kemungkinan (tidak bisa dijelaskan secara pasti karena merupakan prakiraan) sebagai berikut :

1. Data cuaca yang digunakan untuk variabel masukan belum lengkap.

2. Informasi cuaca yang diambil dari tiga daerah belum bisa mewakili seluruh Jawa Barat dan DKI Jakarta.

3. Beban di Jawa Barat dan DKI Jakarta tidak begitu dipengaruhi oleh cuaca.

4. Beban historis yang digunakan untuk variabel masukan JST kurang banyak (hanya 2 hari yang lalu)

5. Putaran (iterasi) maksimum pada waktu pelatihan JST kurang besar.

Bila Sistem prakiraan beban dengan JST ini akan diterapkan pada suatu industri listrik seperti PLN UPB Banjaran dengan tujuan untuk mendapatkan prakiraan beban yang lebih baik (error lebih kecil) masih diperlukan penelitian lebih lanjut.

Tabel 1. Perbandingan Hasil Prakiraan Beban Tanggal 14 Februari 2004.

\begin{tabular}{|c|c|c|c|c|c|}
\hline \multicolumn{4}{|c|}{$\begin{array}{c}\text { PRAKIRAAN BEBAN LISTRIK } \\
\text { HARI SENIN }\end{array}$} & \multicolumn{2}{|c|}{ PROSEN ERROR PRAKIRAAN } \\
\hline \multicolumn{4}{|c|}{ DALAM MW } & \multicolumn{2}{|c|}{ BEBAN HARI SENIN } \\
\hline JAM & Prak. JST & Prak. UPB & Beban Real & $\%$ Error JST & \%Error UPB \\
\hline 1 & 568.39 & 561 & 582.3 & 2.45 & 3.8 \\
\hline 2 & 556.03 & 566 & 569.3 & 2.39 & 0.58 \\
\hline 3 & 551.56 & 644 & 636.1 & 15.33 & 1.23 \\
\hline 4 & 564.39 & 658 & 697.5 & 23.58 & 6 \\
\hline 5 & 622.22 & 640 & 663.2 & 6.59 & 3.63 \\
\hline 6 & 526.03 & 537 & 533.3 & 1.38 & 0.69 \\
\hline 7 & 417.48 & 402 & 419.7 & 0.53 & 4.4 \\
\hline 8 & 473.11 & 440 & 454.4 & 3.95 & 3.27 \\
\hline 9 & 461.74 & 450.9 & 478.3 & 3.59 & 6.08 \\
\hline 10 & 488.55 & 464 & 488.4 & 0.03 & 5.26 \\
\hline 11 & 489.22 & 473 & 487.3 & 0.39 & 3.02 \\
\hline 12 & 464.85 & 445 & 463.8 & 0.23 & 4.22 \\
\hline 13 & 455.8 & 443 & 435.7 & 4.41 & 1.65 \\
\hline
\end{tabular}




\begin{tabular}{|c|c|c|c|c|c|}
\hline 14 & 466.86 & 450 & 458.9 & 1.71 & 1.98 \\
\hline 15 & 480.54 & 466 & 461.3 & 4 & 1.01 \\
\hline 16 & 480.61 & 464 & 455 & 5.33 & 1.94 \\
\hline 17 & 511.09 & 510 & 504 & 1.39 & 1.18 \\
\hline 18 & 674.48 & 720 & 725.3 & 7.53 & 0.74 \\
\hline 19 & 840.2 & 832 & 826 & 1.69 & 0.72 \\
\hline 20 & 844.17 & 826 & 799.4 & 5.3 & 3.22 \\
\hline 21 & 789.95 & 769 & 793.6 & 0.46 & 3.2 \\
\hline 22 & 710.41 & 693 & 723.6 & 1.86 & 4.42 \\
\hline 23 & 675.27 & 654 & 641.3 & 5.03 & 1.94 \\
\hline 24 & 615.73 & 622 & 636.6 & 3.39 & 2.35 \\
\hline Min & 417.48 & 402 & 419.7 & 0.03 & 0.58 \\
\hline Max & 844.17 & 832 & 826 & 23.58 & 6.08 \\
\hline Rata & 572.03 & 572.08 & 580.6 & 4.27 & 2.77 \\
\hline
\end{tabular}

\section{Kesimpulan}

Dari hasil penelitian ini dapat diambil beberapa kesimpulan sebagai berikut :

- Kelebihan JST terletak pada kemampuan belajar yang dimilikinya. Dengan kemampuan tersebut pengguna tidak perlu merumuskan kaidah atau fungsinya. JST akan belajar mencari sendiri kaidah atau fungsi tersebut. Dengan demikian JST mampu digunakan untuk menyelesaikan masalah yang rumit dan atau masalah yang terdapat kaidah atau fungsi yang tidak diketahui (seperti prakiraan beban listrik).

- Kemampuan JST dalam menyelesaikan masalah yang rumit telah dibuktikan dalam penelitian ini (memperkirakan beban listrik).

- Sebagaimana sifat dari penelitian yaitu berhasil atau tidak berhasil. Dalam kasus ini apabila ditinjau dari segi perkembangan teknologi dibidang prakiraan beban penelitian ini belum bisa dikatakan berhasil. Dari segi kemampuan untuk memprakirakan beban, penelitian telah berhasil memprakirakan dengan error rata-rata $6.6438 \%$ dari hasil prakiraan (menurut contoh diatas).

\section{Saran}

Penelitian ini merupakan langkah awal dalam menggunakan JST untuk prakiraan beban di Area 3 (Jawa Barat dan DKI Jakarta) yang masih banyak kekurangannya. Penelitian lebih lanjut diharapkan dapat memperbaiki kekurangan dan mendapatkan hasil prakiraan beban dengan error yang lebih kecil. Untuk mencapai tujuan tersebut diberikan saran sebagai berikut :

1. Digunakan berbagai macam model jaringan misalnya JST Bacpropagation yang lebih sempurna (modifikasi proses belajar), jaringan dengan umpan balik dan penentuan parameter jaringan yang paling tepat. 
2. Fungsi aktivasi yang digunakan setiap sel dalam menghitung keluarannya dapat dibuat dengan variasi lain, asalkan masih memenuhi persaratan yang ditentukan diatas.

3. Pemilihan variabel masukan JST diperbanyak misalnya beban historis yang digunakan lebih dari 2 x 24 jam, dengan parameter cuaca yang lebih lengkap seperti suhu, kelembaban dan arah/kecepatan angin.

4. Jaringan Syaraf Tiruan diaplikasikan dalam bentuk perangkat keras yang didukung oleh sistem mikroprosesor yang telah berkembang maju, sehingga dapat dilakukan peramalan beban secara on-line yang masukannya sinyal dari bus-bus beban dan keluaranya sinyal ke pusatpusat pembangkit.

\section{Daftar Pustaka}

[1] Ayub, Pemakaian Jaringan Syaraf Tiruan Perambatan-Balik Sebagai Cara Lain Prakiraan Beban Jangka Pendek Di Jawa Barat dan DKI Jakarta.. Tugas Akhir Teknik Elektro Fakultas Teknik Elektro, Bandung, 2001.

[2] O. Mohammed, D. Park, R. Merchant, T. Dihn, C. Tong, A. Azeem, "Practical Experiences With An Adaptive Neural Network Short Term Load Forecasting System, IEEE Transaction On Power System, Vol. 10, No. 1, pp 254-265, February 1995.

[3] Kun-Long Ho, Yuan-Yih Hsu and Chen Chuen Yang, "Short Term Load Forecasting Using A Multi Layer Neural Network With An Adaptive Learning Algorithm", IEEE Tr. On Power Sys, Vol. 7, No. 1, Feb. 1992.

[4] K. y. Lee, J. H. Park "Short Term Load Forecasting Using An Artificial Neural Network", IEEE Tr. On power Sys, Vol. 7, No. 1, Feb. 1992.

[5] Shin-Tzo Chen, David C. Yu and A. R. Moghaddamlo, "Weather Sensitive Short Term Load Forecasting Using Non Fully Connected Artificial Neural Network", , IEEE Tr., On Power Sys. Vol. 7, No. 5, Feb. 1992.

[6] Kun Long Ho, Yuan-Yih Hsu, Chuan-Fu chen, Tzong-En Lee, Chih-Chien Liang, Tsan-Shin Lai And Kung-keng chen, Short Term Load Forecasting Of Taiwan Power System Using A. Knowledge Base Expert System, IEEE Tr. On Power Systems, Vol 5, No. 4, November 1990.

[7] EEE Committed Report, " Load Forecasting Bibliography Phase I", IEEE Transaction On Power Apparatus and System, Vol. Pas-99, pp 53-58, 1980.

[8] Laurence Fausett, Fundamental Of Neural Network Architectures, Algorithms And Application, Prentice Hal, Englewood Cliffs, New Jersey, 1994. 